\title{
THE CLINICAL LEARNING ENVIRONMENT: THE ATTITUDE OF UNDERGRADUATE STUDENT NURSES TOWARDS MENTORSHIP AT HOSPITALS IN LITHUANIA
}

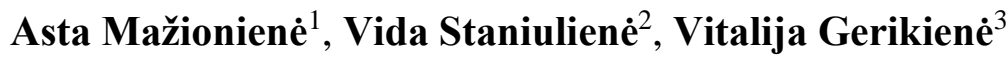

\begin{abstract}
The research sought to determine the attitude of student nurses towards their clinical placement: clinical learning environment, communication with supervisor - mentor, and their satisfaction with the recently completed clinical placement. The research was performed by 283 students of the first to third study year from two Northwest regional higher education institutions for nurses in Lithuania. The students have recently completed their clinical placement at regional hospitals. A quantitative descriptive correlational design was used. The research instrument used was the paper version of the CLES (Clinical Learning Environment and Supervision) questionnaire. The research results revealed that more than half of the students were satisfied with their recently completed clinical placement. Their satisfaction was related to the study year. The student nurses were the most positive about the possibility to approach the members of staff during clinical placement and the fact that there were sufficient meaningful learning cases and situations during clinical placement. Clinical placement of the student nurses was supervised and assessed by supervisors - registered nurses $(\mathrm{N}=133)$ and ward managers $(\mathrm{N}=135)$. The student nurses assessed their personal contribution in clinical placement as good and very good. Those, who specified the highest personal contribution in their clinical placement, assessed the clinical learning environment the best. The most satisfied students were supervised individually during their clinical placements.
\end{abstract}

UDC Classification: 378; DOI: http://dx.doi.org/10.12955/cbup.v6.1229

Keywords: clinical placement, clinical learning environment, student nurses, CLES, Lithuania

\section{Introduction}

The clinical internship placement is the best place to build nursing knowledge. It is an important part of nurse education during which students have the opportunity to translate theory into practice. In the Lithuanian Bachelors of nursing degree, students are required to perform clinical placements of no less than $50 \%$ of their total education time, in line with the European Council recommendation that the clinical component should comprise $50 \%$ of the nursing education programme and take place in healthcare settings (Directive 2013/55/EU). The clinical learning environment (CLE) is a multilevel phenomenon which consist of a pedagogical atmosphere, the leadership style of the ward manager, the premises of nursing, and supervisory relationships (Tomietto et al., 2014). Nursing programmes and healthcare facility leaders must evaluate the CLE, ensuring learning objectives are met, to better prepare students for practice (Flott \& Linden, 2016). In Lithuania, several studies have been conducted in the field of health care students' clinical training. The relationship between a student and a mentor, the students' attitudes toward their clinical training and support from their mentor, the connection between a psychosocial environment and the achievement of the practical training objectives in the practical training settings were investigated (Riklikienè \& Nalivaikiené, 2013). Good interpersonal relationship, communication and support between staff and students create a conducive environment which is essential for students (Kaphagawani \& Useh, 2013). Mentorship within clinical practice is a significant part of nursing education. A mentor facilitates learning, supervises and assess students in the practical placement and have a responsibility to support students to achieve the learning outcomes of practical training.

The study was aimed to reveal undergraduate student nurses' attitudes to mentorship in clinical settings in Lithuania. For the context of the CLES (Clinical Learning Environment and Supervision) questionnaire, the following research questions were presented: 1) what are nursing students' opinions about the clinical environment? 2) what are nursing students' perceptions of the mentoring and mentorship model? 3) what is the relationship between the students' satisfaction with the CLE and dimensions of the CLES?

\section{Background}

In a fast-changing and complex healthcare system, the educational goal of a nursing programme is to educate nurse graduates, who are capable to ensure safety and quality of healthcare. Many changes in nursing education and its status in higher education in Europe have influenced placement learning

\footnotetext{
${ }^{1}$ Klaipeda State University of Applied Sciences, a.mazioniene@kvk.lt

${ }^{2}$ Klaipeda State University of Applied Sciences, v.staniuliene@kvk.lt

${ }^{3}$ Klaipeda State University of Applied Sciences and Šiauliai State College, v.gerikiene@kvk.lt
} 
provisions (Papastavrou et al., 2010). Since nursing is a practice-focused profession, knowledge and skill are acquired through formal education in institutions and through experience in the clinical area, with the latter forming the "clinical learning environment" (CLE) (Gaberson \& Oermann, 2010). From an educational perspective, the clinical environment is the place where skills, knowledge and attitudes are developed, and the theoretical part of the curriculum are applied, developed and integrated (Newton et al., 2010). The CLE is the place where the theoretical components of the curriculum can be integrated with the practical and transformed into professional skills and attitudes within an emotionally safe environment (Steven et al., 2014). Everything that surrounds the student nurse is CLE, including the clinical settings, the equipment, the staff and the patients, the mentor, and the nurse teacher (Papp et al., 2003). Empirical studies have illustrated the transition of interest CLE (Dimitriadou et al., 2015). Initially, the ward manager was the key factor in students' clinical learning, then more supportive and individualized supervision models were developed in order to ensure that the novice learner had a safe practice environment and an effective role model (Holland \& Lauder, 2012). The most recent evidence from established European countries goes forward and reflects on roles of clinical mentors, students' expectations and their mentorship experience in different settings outside the hospital (Antohe et al., 2016). Mentors are also expected to facilitate a supportive learning environment and conduct an assessment on the student's performance and attainment of clinical skills (Ali \& etc., 2008). This role requires mentors to facilitate students' personal and professional growth and the development of nursing competencies (Jokelainen et al., 2013). It has been presented that a mentor acts as a role model, and guides and advises a student (Myall et al., 2008). Several studies focused on student nurses' experiences with the clinical learning environment. A supervisory relationship was found to be the most important factor contributing to clinical learning experiences (Johansson et al., 2010). Their results showed the importance of a good supervisory relationship and their influence on how students experience the clinical learning environment (Antohe et al., 2016).

\section{Data and methodology}

Quantitative research was carried out, seeking to reveal the attitude of the student nurses towards their clinical placement environment. The research questionnaire was presented to students from two higher education institutions from the Northwest regions of Lithuania, who have recently completed their clinical placement at hospitals. Higher education institutions were selected by nonprobability convenience sampling, following the territorial principle. The anonymous survey was completed by $\mathrm{N}=283$ full-time, first to third study year nursing students: $33.2 \%$ were in their first study year, 32.2 $\%$ were in their second study year $34.6 \%$ were in their third study year. The age of the respondents varied from 18 to 50 years old (mean -22.64 years). Most of the respondents $(95.8 \%$ ) were female students, and only a small proportion $(4.2 \%)$ - male students. The majority $(98.6 \%)$ of those surveyed completed their clinical placement at hospitals, while the others in a community environment. $22.3 \%$ of the surveyed students completed their clinical placement in the psychiatry unit, $12,0 \%-$ gynaecology unit, $10.2 \%$ - child diseases unit, $6.7 \%$ - surgery unit, $8.8 \%$ - internal medicine/therapy unit, $11.7 \%$ - geriatric unit, $35.7 \%$ - other unit. The duration of the clinical placement ranged from 2 weeks to 12 weeks. $25.4 \%$ of the surveyed students had 4 weeks of placement, while a slightly lower proportion $(19.6 \%)$ had 5 weeks, and similarly, $19.6 \%$ of the students had 6 weeks of clinical placement. Meanwhile, $21.4 \%$ of the students had 8 weeks, $11.8 \%-$ 2 weeks, and $2.2 \%-10-12$ weeks of clinical placement. Before starting the research, permission to carry out the research was obtained from the heads of the higher education institutions, as well as a consent was obtained from each student to take part in the research.

Research instrument: paper version of the CLES (Clinical Learning Environment and Supervision) questionnaire. The following dimensions of clinical placement experience of the student nurses were examined through the questionnaire: the environment of clinical placement, communication with supervisor - mentor, and satisfaction with the recently completed clinical placement. The permission to use a Lithuanian version of the CLES questionnaire was obtained from PhD Olga Riklikiene, who performed a Psychometric evaluation of the CLES questionnaire. The statements were offered on a 5step continuum scale: 1 , fully disagree; 2 , disagree; 3 , neither agree nor disagree/neutral; 4 , agree; and 5 , fully agree. The data analysis was carried out using SPSS -25 . A non-parametric K independent sample (Kruskal - Wallis) was used to analyse the data and the $\chi^{2}$ criterion was applied. The 
Spearman correlation analysis was used to test the interrelationship between interval measures and the $\mathrm{p}<0.05$ was considered significant.

\section{Results}

The duration of clinical placement ranged from 2 to 12 weeks. Students, whose duration of clinical placement was 2 weeks consisted of $11.8 \%$ of the sample, those whose duration of clinical placement was 4 weeks $25.4 \%$, whose duration of clinical placement was 5 - 6 weeks $39.2 \%$, and finally, those whose duration of clinical placement was $8-12$ weeks consisted of $23.6 \%$ of the student nurses.

More than half $(56.2 \%)$ of the students were satisfied with their clinical placement, $26.5 \%$ of them were very satisfied, and $29.7 \%$ were satisfied, while $28.6 \%$ of the students were neither satisfied nor dissatisfied, and $14.8 \%$ were very or quite dissatisfied with their clinical placement. A statistically significant difference was found within the students' attitude during the first to the third study year $\left(\chi^{2}=41.131 ; \mathrm{df}=8 ; p=0.000\right)$. The students from the first study year, in comparison with the students from the second and third study year, were more satisfied with their recently completed clinical placement.

The research results revealed that while assessing the learning environment in the unit, the students gave the highest score (mean -4.07 out of 5) to the fact that members of the staff were easy to approach. A slightly lower score (mean -3.75 of 5 scores) was given to the fact that they felt comfortable at the start of their shift. The students noted (mean -3.79 of 5 scores) that there were sufficient meaningful learning situations, those situations were diverse and multidimensional in terms of content (mean - 3.77 of 5 scores). The lowest score (mean - 2.41) was given to the possibilities for open discussions at briefings and staff meetings. More than half $(57.6 \%)$ of those surveyed students disagreed with the fact that they had a possibility for open discussions in briefings and staff meetings.

The assessment of the learning environment in the unit was correlated with the duration of placement $(r=0.128, p=0.033)$. A longer duration of placement was directly related with a more positive assessment of the learning environment in the clinical placement (see Table 1) in only two cases: "During staff meetings (e.g., before shifts) I felt comfortable taking part in the discussions" $(r=0.174$, $p=0.004)$ and "The staff learned to know the students by their personal names" $(r=0.186, p=0.002)$.

Table 1. Assessment of the learning environment in the unit and its relationship with duration of placement

\begin{tabular}{|l|c|c|c|c|}
\hline Learning environment in the unit & Mean & SD & \multicolumn{2}{|c|}{$\begin{array}{c}\text { Duration of } \\
\text { Placement }\end{array}$} \\
\cline { 3 - 5 } & & & $\boldsymbol{r}^{*}$ & $\boldsymbol{p}$ \\
\hline Members of the staff were easy to approach & $\mathbf{4 . 0 7}$ & 0.995 & 0.108 & 0.072 \\
\hline $\begin{array}{l}\text { I felt comfortable going to the unit at the start of my } \\
\text { shift }\end{array}$ & 3.75 & 1.040 & 0.082 & 0.171 \\
\hline $\begin{array}{l}\text { During staff meetings (e.g., before shifts) I felt } \\
\text { comfortable taking part in the discussions }\end{array}$ & $\mathbf{2 . 4 1}$ & 1.363 & $\mathbf{0 . 1 7 4}$ & $\mathbf{0 . 0 0 4}$ \\
\hline There was positive atmosphere on the unit & 3.72 & 1.056 & 0.089 & 0.140 \\
\hline $\begin{array}{l}\text { Staff members were generally interested in student } \\
\text { supervision }\end{array}$ & $\mathbf{3 . 3 0}$ & 1.182 & 0.073 & 0.223 \\
\hline $\begin{array}{l}\text { The staff learned to know the students by their } \\
\text { personal names }\end{array}$ & 3.59 & 1.297 & $\mathbf{0 . 1 8 6}$ & $\mathbf{0 . 0 0 2}$ \\
\hline $\begin{array}{l}\text { There were sufficient meaningful learning situations } \\
\text { on the unit }\end{array}$ & $\mathbf{3 . 7 9}$ & 0.956 & 0.014 & 0.816 \\
\hline $\begin{array}{l}\text { Learning situations were multidimensional in terms of } \\
\text { content }\end{array}$ & 3.77 & 0.944 & 0.056 & 0346 \\
\hline $\begin{array}{l}\text { The unit can be regarded as a good learning } \\
\text { environment }\end{array}$ & 3.66 & 1.017 & 0.082 & 0.171 \\
\hline *Spearman correlation coefficient. & & & \\
\hline Source: Authors & & & \\
\hline
\end{tabular}

It was determined that there is statistically significant difference in the students' opinion towards the learning environment at the unit during the first to the third study year $\left(\chi^{2}=98.684 ; \mathrm{df}=62 ; \mathrm{p}=0.002\right)$. The second and the third study years students were more critical than the first study year students. In addition, the second study year students were more critical than the third year students, except for the 
statement: "Staff members were generally interested in student supervision" ( $p>0,05)$. All statements, describing the learning environment in the unit were most positively assessed by the first study year students, and the third study year students were more often positive than the second year students in assessing the learning environment $(\mathrm{p}<0.05)$. In comparison with the second and third year students, the first study year students more often believed that the unit could be regarded as a good example of the learning environment, that there was positive atmosphere in the unit, and that they felt comfortable at the start of their shift in the unit (see Table 2).

Table 2. Distribution of the student opinion towards the learning environment according to the study year

\begin{tabular}{|c|c|c|c|c|c|}
\hline Learning environment in the unit & $\begin{array}{l}\text { Kruskal- } \\
\text { Wallis } \boldsymbol{H}\end{array}$ & $d f$ & $p$ & Study year & $\begin{array}{l}\text { Mean } \\
\text { Rank }\end{array}$ \\
\hline \multirow{3}{*}{$\begin{array}{l}\text { Members of the staff were easy to } \\
\text { approach }\end{array}$} & \multirow[t]{3}{*}{11.982} & \multirow[t]{3}{*}{2} & \multirow{3}{*}{0.003} & First year & 164.46 \\
\hline & & & & Second year & 129.65 \\
\hline & & & & Third year & 131.92 \\
\hline \multirow{3}{*}{$\begin{array}{l}\text { I felt comfortable going to the unit at the } \\
\text { start of my shift }\end{array}$} & \multirow[t]{3}{*}{17.074} & \multirow[t]{3}{*}{2} & \multirow[t]{3}{*}{0.000} & First year & 168.43 \\
\hline & & & & Second year & 122.70 \\
\hline & & & & Third year & 134.58 \\
\hline \multirow{3}{*}{$\begin{array}{l}\text { During staff meetings (e.g.. before shifts) I } \\
\text { felt comfortable taking part in the } \\
\text { discussions }\end{array}$} & \multirow[t]{3}{*}{22.262} & \multirow[t]{3}{*}{2} & \multirow[t]{3}{*}{0.000} & First year & 162.51 \\
\hline & & & & Second year & 110.47 \\
\hline & & & & Third year & 151.60 \\
\hline \multirow[t]{3}{*}{ There was positive atmosphere on the unit } & \multirow[t]{3}{*}{20.523} & \multirow[t]{3}{*}{2} & \multirow[t]{3}{*}{0.000} & First year & $\mathbf{1 7 1 . 3 9}$ \\
\hline & & & & Second year & 122.09 \\
\hline & & & & Third year & 132.29 \\
\hline \multirow{3}{*}{$\begin{array}{l}\text { Staff members were generally interested in } \\
\text { student supervision }\end{array}$} & \multirow[t]{3}{*}{5.729} & \multirow[t]{3}{*}{2} & \multirow[t]{3}{*}{0.057} & First year & 157.52 \\
\hline & & & & Second year & 130.73 \\
\hline & & & & Third year & 137.58 \\
\hline \multirow{3}{*}{$\begin{array}{l}\text { The staff learned to know the students by } \\
\text { their personal names }\end{array}$} & \multirow[t]{3}{*}{7.540} & \multirow[t]{3}{*}{2} & \multirow[t]{3}{*}{0.023} & First year & $\mathbf{1 6 0 . 3 1}$ \\
\hline & & & & Second year & 134.10 \\
\hline & & & & Third year & 131.77 \\
\hline \multirow{3}{*}{$\begin{array}{l}\text { There were sufficient meaningful learning } \\
\text { situations on the unit }\end{array}$} & \multirow[t]{3}{*}{22.265} & \multirow[t]{3}{*}{2} & \multirow[t]{3}{*}{0.000} & First year & $\mathbf{1 7 0 . 0 9}$ \\
\hline & & & & Second year & 117.38 \\
\hline & & & & Third year & 136.42 \\
\hline \multirow{3}{*}{$\begin{array}{l}\text { Learning situations were multidimensional } \\
\text { in terms of content }\end{array}$} & \multirow[t]{3}{*}{23.194} & \multirow[t]{3}{*}{2} & \multirow[t]{3}{*}{0.000} & First year & 169.99 \\
\hline & & & & Second year & 114.98 \\
\hline & & & & Third year & 140.24 \\
\hline The unit can be regarded as a good & 24.313 & 2 & 0.000 & First year & $\mathbf{1 7 2 . 5 3}$ \\
\hline learning environment & & & & Second year & 116.51 \\
\hline & & & & Third year & 136.39 \\
\hline
\end{tabular}

The majority $(69.3 \%)$ of the surveyed students stated that it was very important for them that their placement mentor would be a nurse. $23.7 \%$ of the students noted that it was slightly important and only a few $(6.7 \%)$ students said that it was not important for them to have nurse as their placement mentor. The placement mentor is the one, who supervises, supports, and assesses a student nurse during their clinical placement. The results of this research revealed that almost half $(\mathrm{N}=133,47.0 \%)$ of those surveyed were supervised and assessed by the mentor - registered nurse. A similar number $(\mathrm{N}=135,47.7 \%)$ of students specified that their clinical placement was supervised by a ward manager, and only a few ( 2.5 percent) students noted that they had no supervisor among nurses but instead were taken care of by a teacher from the university of applied sciences. A statistically significant difference between the attitude of the students, supervised by ward manager, and those supervised by a registered nurse, was found.

Students who were supervised and assessed by a supervisor, a registered nurse, during their clinical placement more often specified than those supervised by ward manager, that there was positive atmosphere in the unit, staff members were generally interested in student supervision, students felt comfortable going to the unit at the start of their shift, and members of the staff were easy to approach $(\mathrm{p}<0.05)$. 
Table 3. Distribution of the student attitude towards the learning environment according to the mentor of the clinical placement

\begin{tabular}{|c|c|c|c|c|c|}
\hline Learning environment in the unit & $\begin{array}{c}\text { Kruskal- } \\
\text { Wallis } \\
\text { H }\end{array}$ & 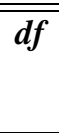 & $p$ & $\begin{array}{l}\text { Mentor of clinical } \\
\text { placement }\end{array}$ & $\begin{array}{l}\text { Mean } \\
\text { Rank }\end{array}$ \\
\hline \multirow{2}{*}{$\begin{array}{l}\text { Members of the staff were easy to } \\
\text { approach }\end{array}$} & \multirow[t]{2}{*}{4.737} & \multirow[t]{2}{*}{4} & \multirow[t]{2}{*}{0.315} & Ward manager & 139.65 \\
\hline & & & & Registered nurse & 147.60 \\
\hline \multirow{2}{*}{$\begin{array}{l}\text { I felt comfortable going to the unit at } \\
\text { the start of my shift }\end{array}$} & \multirow[t]{2}{*}{9.254} & \multirow[t]{2}{*}{4} & \multirow[t]{2}{*}{0.055} & Ward manager & 140.78 \\
\hline & & & & Registered nurse & 147.97 \\
\hline \multirow{2}{*}{$\begin{array}{l}\text { During staff meetings (e.g., before } \\
\text { shifts) I felt comfortable taking part } \\
\text { in the discussions }\end{array}$} & \multirow[t]{2}{*}{11.017} & \multirow[t]{2}{*}{4} & \multirow[t]{2}{*}{0.026} & Ward manager & 132.02 \\
\hline & & & & Registered nurse & 155.17 \\
\hline \multirow{2}{*}{$\begin{array}{l}\text { There was positive atmosphere on the } \\
\text { unit }\end{array}$} & \multirow[t]{2}{*}{12.547} & \multirow[t]{2}{*}{4} & \multirow[t]{2}{*}{0.014} & Ward manager & 137.23 \\
\hline & & & & Registered nurse & 152.60 \\
\hline \multirow{2}{*}{$\begin{array}{l}\text { Staff members were generally } \\
\text { interested in student supervision }\end{array}$} & \multirow[t]{2}{*}{12.529} & \multirow[t]{2}{*}{4} & \multirow[t]{2}{*}{0.014} & Ward manager & 133.61 \\
\hline & & & & Registered nurse & 154.11 \\
\hline \multirow{2}{*}{$\begin{array}{l}\text { Learning situations were } \\
\text { multidimensional in terms of content }\end{array}$} & \multirow[t]{2}{*}{10.779} & \multirow[t]{2}{*}{4} & \multirow[t]{2}{*}{0.029} & Ward manager & 131.21 \\
\hline & & & & Registered nurse & 153.75 \\
\hline
\end{tabular}

The students assessed the leadership of a ward manager by giving them a score of 3.77 out of a possible 5-score scale. A higher score (3.84) was given to the statement that the efforts of each employee were evaluated. The lowest score (mean -3.61) was given to the statement that the feedback from a ward manager was used for supervision in a fast manner. Even one third $(32.2 \%)$ of those surveyed doubted whether a ward manager considers staff members as key resources.

One third $(32.5 \%)$ of the students stated that the individual supervision model was used in their clinical placement, where a nurse mentor took care of each student individually. According to most of the students $(41.0 \%)$ a group supervision model was applied in their clinical placement, where one mentor nurse took care of a few students, and around one fifth $(19.8 \%)$ of those surveyed noted that no supervisor was appointed to them during their clinical placement. A statistically significant difference was found in the student attitudes, for the assessment of the learning environment in the unit, according to the supervision (i.e., mentorship, support, and assessment) model applied in the clinical placement $\left(\chi^{2}=148.549 ; \mathrm{df}=93 ; \mathrm{p}=0.000\right)$.

Table 4. Assessment of the learning environment in the unit, according to the supervision model applied in the clinical placement

\begin{tabular}{|l|c|c|c|}
\hline \multirow{2}{*}{ Learning environment in the unit } & \multicolumn{3}{|c|}{ Supervision Model } \\
\cline { 2 - 4 } & $\chi^{2}$ & df & $\boldsymbol{p}$ \\
\hline Members of the staff were easy to approach & 54.172 & 15 & 0.000 \\
\hline I felt comfortable going to the unit at the start of my shift & 50.095 & 12 & 0.000 \\
\hline $\begin{array}{l}\text { During staff meetings (e.g., before shifts) I felt comfortable taking } \\
\text { part in the discussions }\end{array}$ & 42.156 & 12 & 0.000 \\
\hline There was positive atmosphere on the unit & & & \\
\hline Staff members were generally interested in student supervision & 53.071 & 12 & 0.000 \\
\hline The staff learned to know the students by their personal names & 47.837 & 12 & 0.000 \\
\hline There were sufficient meaningful learning situations on the unit & 35.030 & 15 & 0.000 \\
\hline Learning situations were multidimensional in terms of content & 24.360 & 12 & 0.000 \\
\hline The unit can be regarded as a good learning environment & 45.608 & 12 & 0.018 \\
\hline Source: Authors & \multicolumn{3}{|l}{} \\
\hline
\end{tabular}

Students, who were subjected to the individual supervision model, where the supervisor - a registered nurse, took care of each student individually, were more positive in assessing the learning environment in the unit than those who were subject to group supervision or other models during their clinical placement. All statements, describing learning environment in the unit, were more positively assessed by the students, who were subjected to the individual supervision model $(\mathrm{p}<0.05)$. These students felt a positive atmosphere in the unit, felt comfortable before their shift in the unit, the staff members more 
often knew students by their names and the staff members were interested in the supervision (see Table 5).

Table 5. Distribution of the student attitude towards the learning environment in the unit, according to the supervision model applied in their clinical placement

\begin{tabular}{|c|c|c|c|c|c|}
\hline Learning environment in the unit & $\begin{array}{l}\text { Kruskal- } \\
\text { Wallis } \\
\text { H }\end{array}$ & $d f$ & $p$ & Supervision Model & $\begin{array}{l}\text { Mean } \\
\text { Rank }\end{array}$ \\
\hline \multirow{4}{*}{$\begin{array}{l}\text { Members of the staff were easy to } \\
\text { approach }\end{array}$} & \multirow[t]{4}{*}{31.437} & \multirow[t]{4}{*}{3} & \multirow[t]{4}{*}{0.000} & Group & 139.46 \\
\hline & & & & Individual & 170.68 \\
\hline & & & & Other else & 149.05 \\
\hline & & & & Any supervisor & 97.76 \\
\hline \multirow{4}{*}{$\begin{array}{l}\text { I felt comfortable going to the unit at the } \\
\text { start of my shift }\end{array}$} & \multirow[t]{4}{*}{41.462} & \multirow[t]{4}{*}{3} & \multirow[t]{4}{*}{0.000} & Group & 134.07 \\
\hline & & & & Individual & $\mathbf{1 7 7 . 3 5}$ \\
\hline & & & & Other else & 159.50 \\
\hline & & & & Any supervisor & 94.42 \\
\hline \multirow{4}{*}{$\begin{array}{l}\text { During staff meetings (e.g., before shifts) } \\
\text { I felt comfortable taking part in the } \\
\text { discussions }\end{array}$} & \multirow[t]{4}{*}{35.126} & \multirow[t]{4}{*}{3} & \multirow[t]{4}{*}{0.000} & Group & 129.37 \\
\hline & & & & Individual & $\mathbf{1 7 8 . 5 5}$ \\
\hline & & & & Other else & 150.97 \\
\hline & & & & Any supervisor & 105.06 \\
\hline \multirow{4}{*}{$\begin{array}{l}\text { There was positive atmosphere on the } \\
\text { unit }\end{array}$} & \multirow[t]{4}{*}{52.477} & \multirow[t]{4}{*}{3} & \multirow[t]{4}{*}{0.000} & Group & 132.93 \\
\hline & & & & Individual & 181.73 \\
\hline & & & & Other else & 162.82 \\
\hline & & & & Any supervisor & 88.46 \\
\hline \multirow{4}{*}{$\begin{array}{l}\text { Staff members were generally interested } \\
\text { in student supervision }\end{array}$} & \multirow[t]{4}{*}{43.573} & \multirow[t]{4}{*}{3} & \multirow[t]{4}{*}{0.000} & Group & 137.86 \\
\hline & & & & Individual & 176.06 \\
\hline & & & & Other else & 159.87 \\
\hline & & & & Any supervisor & 88.56 \\
\hline \multirow{4}{*}{$\begin{array}{l}\text { The staff learned to know the students by } \\
\text { their personal names }\end{array}$} & \multirow[t]{4}{*}{44.781} & \multirow[t]{4}{*}{3} & \multirow[t]{4}{*}{0.000} & Group & 128.06 \\
\hline & & & & Individual & $\mathbf{1 8 3 . 5 3}$ \\
\hline & & & & Other else & 150.18 \\
\hline & & & & Any supervisor & 99.87 \\
\hline \multirow{4}{*}{$\begin{array}{l}\text { There were sufficient meaningful } \\
\text { learning situations on the unit }\end{array}$} & \multirow[t]{4}{*}{28.056} & \multirow[t]{4}{*}{3} & \multirow[t]{4}{*}{0.000} & Group & 137.87 \\
\hline & & & & Individual & 170.99 \\
\hline & & & & Other else & 137.79 \\
\hline & & & & Any supervisor & 102.37 \\
\hline Learning situations were & 20.976 & 3 & 0.000 & Group & 134.54 \\
\hline multidimensional in terms of content & & & & Individual & 169.73 \\
\hline & & & & Other else & 141.11 \\
\hline & & & & Any supervisor & 112.20 \\
\hline The unit can be regarded as a good & 37.479 & 3 & 0.000 & Group & 137.00 \\
\hline learning environment & & & & Individual & $\mathbf{1 7 2 . 7 8}$ \\
\hline & & & & Other else & 165.66 \\
\hline & & & & Any supervisor & 93.77 \\
\hline
\end{tabular}

Source: Authors

The students expressed their opinion about their personal contribution to clinical placement. More than four fifths $(83.6 \%)$ of the surveyed students assessed their personal contribution in this clinical placement as 4 out of a possible score of 5. Only a small proportion $(14.8 \%)$ of the students assessed their personal contribution as a 3 out of 5 . The general mean of personal contribution in this clinical placement was 4.15 out of 5 . The assessment of students' personal contribution in clinical placement was directly correlated with assessment of the learning environment in the unit $(r=0.311, p=0.000)$. The personal contribution in the clinical placement, assessed by higher score, was directly related with a more positive assessment of the learning environment in the nursing unit $(r=0.312, p=0.000)$, and the leadership style of the ward manager $(r=0.238, p=0.000)$.

The highest mean score (4.15) was given to the nursing care in the unit where the students had their clinical placement. $80.2 \%$ of those surveyed agreed that the patients in their units had individual 
nursing and care. The lowest score (mean - 3.51) was given to the statement that information about the patient care was disseminated without any problems in the unit. This statement was agreed by more than half $(52.6 \%)$ of the surveyed students.

\section{Discussion}

The evaluation of effectiveness of the selected factors influencing the student perceptions of clinical learning environment has been of interest to many investigators in a number of quantitative and qualitative studies (Gurkova et al., 2016). This includes staff - student relationships and meaningful learning situations constituting a pedagogic atmosphere (Saarikoski et al., 2002). In our study we have used the term mentorship to explain relations between the mentors and students during the survey. Antohe et al. (2016) state that supervision and mentoring are supportive relationships, which help individuals to obtain new skill, knowledge and approaches. Students mentorships require qualified and experienced nurses to act as mentors for individual students (Jokelainen et al., 2013).

The study results revealed statistically significant differences between the attitude of the students supervised by ward manager and students supervised by registered nurse. Students who were supervised and assessed by a registered nurse during clinical placement, more often than the students, supervised by ward manager, specified that there was positive atmosphere in the unit, staff members were generally interested in student supervision, students felt comfortable going to the unit at the start of their shift, and members of the staff were easy to approach $(\mathrm{p}<0.05)$. On the contrary Riklikiené, Nalivaikienè (2013) did not find any statistically significant difference between the groups of students supervised by different mentors ( $p>0.05$ ), though student nurses supervised by a registered nurse rated the pedagogical atmosphere in the ward better than ward manager. Similar findings were reported in the Antohe (2016) study, where the supervisory role of the staff nurses was very important; the most common supervisory experience was a successful individualised supervisory relationship and the majority of the students stated their own staff nurse mentor was the most important professional role model for them. Our study findings explored that students who were supervised by the individual supervision model, more positively assessed the learning environment in the unit, $(\mathrm{p}<0,05)$, than students who were supervised by the group supervision or other model during their clinical placement. Those individually supervised students felt a positive atmosphere in the unit, felt comfortable before their shift in the unit, the staff members more often knew students by their names and the staff members were interested in the supervision. The Bachelors students in nursing highlighted the importance of positive relationships between student and mentor under influence of their own as well as their supervisors' attitudes and competences (Antohe et al., 2016).

Student nurses estimated their individual input into clinical training mostly as high or very high. The correlation analysis revealed a positive relationship between the students' assessment of the learning environment in the unit and their individual input to their practical placement. The study findings are in line with the study by Riklikienè \& Nalivaikienè (2013), where students' individual input in their practical learning were underemphasized.

These study findings showed that students of the first study year, in comparison with the students of the second and third study year, were more satisfied with their recently completed clinical placement. Papastavrou et al., (2016) supports these study findings, that specifically the first year students had the highest satisfaction level compared to the other years $\left(2^{\text {nd }}\right.$ to $\left.4^{\text {th }}\right)$. Bjork et al., (2014) emphasized that the students' high scores on personalisation and student involvement in different studies with CLES indicate that students often enter into a responsive and trusting relationship with their supervisors regardless of clinical placement setting.

\section{Conclusions}

More than half of the students were satisfied with their clinical placement, and almost one third of them were very satisfied. The learning environment in the unit was more positively evaluated by the first year students, while the third year students often were more positive in assessing their learning environment in the unit than the students of the second year. The nursing students best assessed the possibility to address the staff and the fact that there were enough training cases and situations during their clinical placement. A higher score, given to the personal contribution of a student in the clinical placement, was directly related with a more positive assessment of the learning environment in the 
unit. Those students, who were supervised and evaluated by a mentor - a nurse during their clinical placement, were more satisfied that those, who were supervised by a nursing administrator.

The most satisfied students were subject to an individual supervision model during their clinical placement.

\section{References}

Ali, P.A. and Panther, W. Professional development and the role of mentorship. Nursing Standard. 2008; 22: 35-39. PMid:18649718.

Antohe, I., Riklikiene, O., Tichelaar, E., Saarikoski, M. (2016). Clinical education and training of student nurses in four moderately new European Union countries: Assessment of students' satisfaction with the learning environment. Nurse Education in Practice. 2016 Mar;17:139-144. http://dx.doi.org/10.1016/j.nepr.2015.12.005.

Bjork, I. T., Berntsen, K, Brynildsen, G. And Hestetun, M. (2014). Nursing students' perceptions of their clinical learning environment in placements outside traditional hospital settings. Journal of Clinical Nursing, 23, 2958-2967, doi: 10.1111/jocn.12532.

Dimitriadou, M., Papastavrou, E., Efstathiou, G. And Theodorou, M. (2015). Baccalaureate nursing students' perceptions of learning and supervision in the clinical environment. Nursing and Health Sciences, (2015), 17, 236-242.

European Parliament. Directive 2013/55/EU of the European Parliament and of the council of 20 November 2013 amending Directive 2005/36/EC on the recognition of professional qualifications and Regulation (EU) No 1024/2012 on administrative cooperation through the Internal Mark. Off J Eur Union. 2013:132-170.

Flott, E. A., Linden, L. (2016). The clinical learning environment in nursing education: a concept analysis. Journal of Advanced Nursing 72(3), 501-513.

Gaberson, KB, Oermann, MH. (2010). Clinical Teaching Strategies in Nursing, (3 $3^{\text {rd }}$ edn). New York, NY: Springer, 2010 ; 1 12.

Gurkova, E., Žiakova, K., Cibrikova, S., Magurova, D., Hudakova, A., Mroskova, S. (2016). Factors influencing the effectiveness of clinical learning environment in nursing education. Central European Journal of Nursing and Midwifery, 7(3), 470-475, doi: 10.15452/CEJNM.2016.07.0017.

Holland, K., Lauder, W.A. review of evidence for the practice learning environment: enchanging the context for nursing and midwifery care in Scotland. Nurse Educ. Pract. 2012; 12: 60-64.

Johansson, U.-B., Kaila, P., Ahlner-Elmqvist, M., Leksell, J., Isoaho, H. \& Saarikoski, M. (2010). Clinical learning environment, supervision and nurse teacher evaluation scale: psychometric evaluation of the Swedish version. Journal of Advanced Nursing 66(9), 2085-2093. doi: 10.1111/j.1365-2648.2010.05370.x

Jokelainen, M., Jamookeeah, Tossavainen, K., Turunen, H. (2013). Mentorship provision for student nurses: Conceptions of Finnish and British mentors in healthcare placements. Journal of Nursing Education and Practice, 2013, Vol. 3, No. 2. www.sciedu.ca/jnep.

Kaphagawani, N.C., Useh, U. (2013). Analysis of Nursing Students Learning Experiences in Clinical Practice: Literature Review. Ethno Med, 7(3): 181-185.

Myall, M., Levett-Jones, T. And Lathlean, J. Mentorship in contemporary practice: the experiences of nursing students and practice mentors. Journal of Clinical Nursing. 2008; 17: 1834-1842. http://dx.doi.org/10.1111/j.1365-2702.2007.02233.x

Newton, JM., Jolly, BC., Ockerby, CM \& Cross, WM (2010). A Clinical Learning Environment Scale: a factor analysis, Journal of Advanced Nursing 66, 1371-1481.

Papastavrou, E., Dimitriadou, M., Tsangari, H., Andreou, C. Nursing students'satisfaction of the clinical learning environment: a research study. BMC Nursing. 2016; 15:44. Doi 10.1186s12912-016-0164-4.

Papastavrou, E., Lambrinou, E., Tsangari, H., Saarikoski, M. and Leino-Kilpi, H. (2013). Student nurses experience of learning in the clinical environment. Nurse Education in Practice. 2010; 10: 176-182. http://dx.doi.org/10.1016/j.nepr.2009.07.003

Papp, I. Markkanen, M., Von Bonsdorff, M. Clinical environment as a learning environment: student nurses' perceptions concerning clinical learning experiences. Nurse. Educ. Today 2003; 23: 262-268.

Riklikiene, O., Nalivaikiene, R. (2013). Student Nurses’ Assessment of Pedagogical Atmosphere on the Ward During Practical Placement at a University Hospital in Lithuania. NERP;5:182-8.

Saarikoski, M., Leino-Kilpi, H., Warne, T. Clinical learning environment and supervision: testing a research instrument in an international comparative study. Nurs Educ Today. 2002; 22(4):340-349.

Steven, A., Magnusson, C., Smith, P., Pearson, PH. Patient safety in nursing education: contexts, tensions and feeling safe to learn. Nurse Educ Today. 2014; 34:277-84.

Tomietto, M., Comparcini, D., Saarikoski, M., Simonetti, V., Cicolini,G. (2014). Multilevel perspectives in clinical learning environments' assessment: An insight on levels involved in planning nursing. Journal of Nursing Education and Practice, Vol, No 12, www.sciedu.ca/jnep. 